P. JOHANNESSON* ET AL. (ASTRAZENECA GOTHENBURG, MÖLNDAL, SWEDEN)

Discovery of Second Generation Reversible Covalent DPP1 Inhibitors Leading to an Oxazepane Amidoacetonitrile Based Clinical Candidate (AZD7986)

J. Med. Chem. 2016, 59, 9457-9472, DOI: 10.1021/acs.jmedchem.6b01127.
Category

Synthesis of Natural

Products and

Potential Drugs

\section{Synthesis of Brensocatib}<smiles>Cn1c(=O)oc2ccc(B3OC(C)(C)C(C)(C)O3)cc21</smiles>

$[\mathrm{A}]^{*}$

90 LCAP

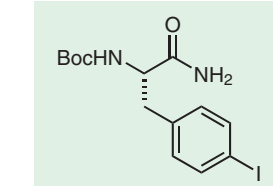

B (0.9 equiv)

$\mathrm{PdCl}_{2}$ (dppf) (0.014 equiv) $\mathrm{K}_{2} \mathrm{CO}_{3}$ (13 equiv) dioxane- $\mathrm{H}_{2} \mathrm{O}, 75^{\circ} \mathrm{C}, 3 \mathrm{~h}$ $2.54 \mathrm{~mol}$ scale

* [] denotes a product used in the next step without further purification

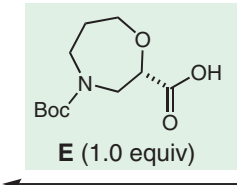

T3P (1.4 equiv) DIPEA (3.0 equiv) DMF, r.t., $0.5 \mathrm{~h}$ $2.35 \mathrm{~mol}$ scale<smiles>Cn1c(=O)oc2ccc(-c3ccc(CC(NC(=O)OC(C)(C)C)C(N)=O)cc3)cc21</smiles>

C] $]^{*}$

white solid 94.3 LCAP

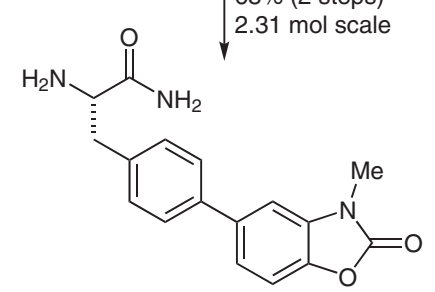
[D] $]^{*}$ off white solid 99.4 LCAP

$$
\mid \begin{aligned}
& \mathrm{HCl} \text { (5.7 equiv) } \\
& \mathrm{CH}_{2} \mathrm{Cl}_{2} \text {-dioxane, } \\
& 68 \% \text { (2 steps) }
\end{aligned}
$$

T3P (2.9 equiv) DIPEA (3.0 equiv) DMF, $50{ }^{\circ} \mathrm{C}, 4 \mathrm{~h}$ then r.t. o/n $98 \%$ (2 steps)<smiles>Cn1c(=O)oc2ccc(-c3ccc(C[C@H](C#N)NC(=O)[C@H]4CN(C(=O)OC(C)(C)C)CCCO4)cc3)cc21</smiles>

$\mathrm{HCO}_{2} \mathrm{H}-\mathrm{H}_{2} \mathrm{O}(10: 1)$ $35^{\circ} \mathrm{C}, 3 \mathrm{~h}$; recryst ex $\mathrm{EtOH}-\mathrm{H}_{2} \mathrm{O}$ $56 \%$ (3.2 mol scale) 98.4 LCAP
Key words

brensocatib

cathepsin C inhibitor

COVID-19

Suzuki-Miyaura coupling

$\alpha$-aminonitrile

dehydration
Significance: Cathepsin C (CatC) is a cysteine dipeptidyl amino-peptidase that activates tissue-degrading elastase-related serine proteases. Brensocatib is a potent reversible CatC inhibitor that was originally developed by AstraZeneca for the treatment of chronic obstructive pulmonary disorder. It is now being evaluated as a treatment for proteasedriven respiratory tissue degradation associated with COVID-19 infections (J. Med. Chem. 2020, 63, DOI: 10.1021/acs.jmedchem.0c00776). Brensocatib was granted breakthrough therapy designation by the FDA in 2020 for the treatment of non-cystic fibrosis bronchiectasis.
Comment: For a detailed description of the molscale synthesis of the fragments A, B, and E and their union see the associated patent (WO 2015 110826). After the Suzuki coupling that assembles biaryl C, $\alpha$-aminonitrile $\mathbf{G}$ was installed by dehydration of $\alpha$-aminocarboxamide $\mathbf{F}$ with T3P (propanephosphonic anhydride). The $\alpha$-aminonitrile could also be installed by dehydration of B prior to Suzuki coupling. 